\title{
Soil conservation practices in a watershed in Southern Brazil
}

\author{
TIAGO S. TELLES ${ }^{1}$, MARCO A.P. LOURENÇO ${ }^{2}$, JOSÉ F. OLIVEIRA ${ }^{2}$, \\ GUSTAVO V. COSTA ${ }^{3}$ and GRAZIELA M.C. BARBOSA ${ }^{2}$ \\ ${ }^{1}$ Área de Socioeconomia, Instituto Agronômico do Paraná, Rod. Celso Garcia Cid, Km 375, 86047-902 Londrina, PR, Brazil \\ 2 Área de Solos, Instituto Agronômico do Paraná, Rod. Celso Garcia Cid, Km 375, 86047-902 Londrina, PR, Brazil \\ ${ }^{3}$ Departamento de Agronomia, Universidade Estadual de Londrina, Rod. Celso \\ Garcia Cid, Km 380, 86057-970 Londrina, PR, Brazil
}

Manuscript received on June 6, 2018; accepted for publication on September 21, 2018

\begin{abstract}
How to cite: TELLES TS, LOURENÇO MAP, OLIVEIRA JF, COSTA GV AND BARBOSA GMC. 2019. Soil conservation practices in a watershed in Southern Brazil. An Acad Bras Cienc 91: e20180578. DOI. 10.1590/0001-3765201920180578.

Abstract: The aim of this study was to determine how often rural farmers in a watershed use no-tillage systems combined with crop rotation, contour farming and agricultural terraces. The study area was Paraná Watershed III (PB3) in the western region of Paraná State, and data from the 2006 Agricultural Census of the Brazilian Institute of Geography and Statistics were used. A frequency distribution analysis of farms as a function of the no-tillage (NT) area was conducted in combination with a cluster analysis of soil and water conservation practices (adoption of crop rotation, contour farming and agricultural terrace practices). The results showed that the farms in PB3 adopt adequate soil and water conservation practices, with $73 \%$ adopting NT combined with at least 2 other conservation practices; however, agricultural terracing was found to be the most neglected practice in the region. In addition, based on the soil and water conservation practices in the watershed, 5 groups of farms were identified, the worst of which, those located in the municipalities that mainly neglect conservation practices, live in areas with highly erodible soils.
\end{abstract}

Key words: contour farming, agricultural terraces, crop rotation, conservation agriculture.

\section{INTRODUCTION}

Soil degradation is associated with a decline in the quality of the physical, chemical, biological and ecological attributes of soil that result in a loss of soil biodiversity, structure and organic matter through erosion and compaction processes, as well as in impaired ecosystem functions and services (Lal 2015). It is estimated that $40 \%$ of the soils used in agricultural production worldwide are

Correspondence to: Tiago Santos Telles

E-mail: telles@iapar.br

ORCid: http://orcid.org/0000-0001-5817-3420 severely degraded due to inadequate management (Jie et al. 2012) and that approximately 12 million hectares of agricultural land is lost due to increased degradation, resulting in reduced production capacity (Rickson et al. 2015). The same scenario applies to Brazil, where the marked degradation of agricultural land has generated annual losses of more than 600 million tons of soil due to erosion at an estimated cost of 1.3 billion dollars a year (Dechen et al. 2015).

In an attempt to control and revert the problems caused by soil erosion, conservation practices have been applied in Brazilian agriculture, including no- 
tillage (NT) and no-tillage systems (NTS) ${ }^{1}$. NT is a widely adopted technique in Brazilian agriculture that is practiced on approximately $50 \%$ of the area cultivated with temporary crops in Brazil (FuentesLlanillo et al. 2013). Several studies have reported it to be an effective practice for controlling losses due to erosion (Silva and De Maria 2011).

The results obtained for Paraná State, which is one of the pioneers in the adoption and development of NT and NTS in Brazil (Silva et al. 2009), have shown that NT controls more than $70 \%$ of soil losses due to erosion compared to conventional tillage practices (Merten et al. 2015), but the reduction of such losses has led many farmers to believe that NT alone is sufficient for controlling soil erosion, leading to the abandonment of agricultural terraces and contour farming (Denardin et al. 2008). In addition, terraces have been eliminated because they are thought to be a barrier to increasingly large agricultural machinery (Telles et al. 2013) and because of the belief that their elimination leads to efficiency gains through mechanized sowing, fertilizer application and harvesting operations.

Despite the establishment of soil and water conservation techniques in Brazilian agriculture, many problems related to soil erosion that are intrinsic to conventional tillage systems are being observed in NT areas (Didoné et al. 2014). From a soil conservation perspective, this return of erosive processes in NT areas is a serious problem for Brazilian agriculture. This scenario has revived discussion about the importance of complementary soil conservation practices (mechanical, edaphic or vegetative) to crop production in the country

\footnotetext{
${ }^{1}$ NTS, also known as conservation agriculture - CA (Kassam et al. 2009), is a production system based on three interlinked principles, namely: no or minimum mechanical soil disturbance (sowing in undisturbed soil and disturbing only the planting furrows - no-tillage), crop species diversification (crop rotation) and biomass mulch soil cover (maintaining permanent soil cover, dead or living) (Muzzili 1983, Kassam et al. 2019).
}

(Barbosa et al. 2012). However, NT alone, without the use of complementary conservation practices, cannot fully control soil losses, let alone the water losses, as many mistakenly believe (Marioti et al. 2013).

Thus, the subject of this study was to assess whether such circumstances are observed in Paraná Watershed III (PB3), which is one of the most important in the country and lies between western Paraná State and southern Mato Grosso do Sul State. This area is rich in natural resources and biodiversity, has abundant water and excellent soils and is known for its high agricultural productivity using modern, mechanized, intensive and highly technical systems (Fuentes-Llanillo et al. 2006). According to the Paraná Institute of Economic and Social Development (IPARDES 2013), PB3 is characterized by soils with low erosion potential that account for $85.52 \%$ of the area. However, even in PB3, soil conservation problems are believed to be related to the abandonment of conservation practices in NT areas, which leads to questions about the quality of NT in PB3 because there can be considerable heterogeneity in how NT is applied, even at the watershed scale. Thus, the Agricultural Research Institute of Paraná State (IAPAR) and Itaipu Binacional together created the concept of a "no-tillage system with quality" (Muzilli 2006) to clarify to farmers that NT should be adopted in conjunction with other conservation practices. However, there is a lack of information regarding how rural farmers implement NT and other conservation practices and the effects of these practices on soil and water conservation at the watershed scale (Didoné et al. 2015).

In this context, the aim of this study was to assess how often rural farmers in a watershed perform NT combined with crop rotation, contour farming and agricultural terraces. 


\section{MATERIALS AND METHODS}

The study area was PB3, which is between $24^{\circ} 01^{\prime} \mathrm{S}$ and $25^{\circ} 35^{\prime} \mathrm{S}$ latitudes and $53^{\circ} 26^{\prime} \mathrm{W}$ and $54^{\circ} 37^{\prime} \mathrm{W}$ longitudes and comprises an area of approximately $8,000 \mathrm{~km}^{2}$, encompassing 24,150 farms distributed in 29 municipalities: 28 are in the western Paraná State, and 1 is in southern Mato Grosso do Sul State (Figure 1). The area is composed by basaltic (Serra Geral Formation) and sandstone rocks (Caiuá Formation), as well as plateau areas and terrain that gently slopes to the west. The region has a Cfa subtropical climate (Köppen-Geiger classification), and the soils are predominantly Latossolos (Hapludox), Nitossolos (Rhodudults), Neossolos (Udorthents) and Argissolos (Paleudult), according to the Brazilian System of Soil Classification SiBCS (Santos et al. 2013) and the United States Department of Agriculture (USDA) classification system (Soil Survey Staff 1999). The PB3 area is mostly occupied by intensive agriculture.

The data used in the study were obtained by special tabulations of the 2006 Agricultural Census of the Brazilian Institute of Geography and Statistics (IBGE) and only refer to NT areas with temporary crops, which are areas planted with or under preparation for planting short-term crops (usually less than one year, except for crops such as sugarcane and cassava) that generally needed to be replanted after each harvest. To assess the adoption level of this practice by the PB3 municipalities, 7 percentage ranges were established to quantify the NT areas with temporary crops: (i) from 38 to $40 \%$, (ii) from 41 to $50 \%$, (iii) from 51 to $60 \%$, (iv) from 61 to $70 \%$, (v) from 71 to $80 \%$, (vi) from 81 to $90 \%$ and (vii) from 91 to $100 \%$.

Additionally, to appraise the soil and water conservation practices in PB3 municipalities, the frequency of implementing crop rotation, contour farming and agricultural terrace practices by the studied farms was determined to assess the adoption level of each soil conservation practice. In the 2006 Agricultural Census, these conservation practices were conceptually defined as follows: (a) contour farming - planting according to the soil contour lines so the plants themselves are a barrier to contain or slow the transport of rainwater, thereby avoiding the formation of rainwater torrents that cause erosion; (b) agricultural terraces - a technique

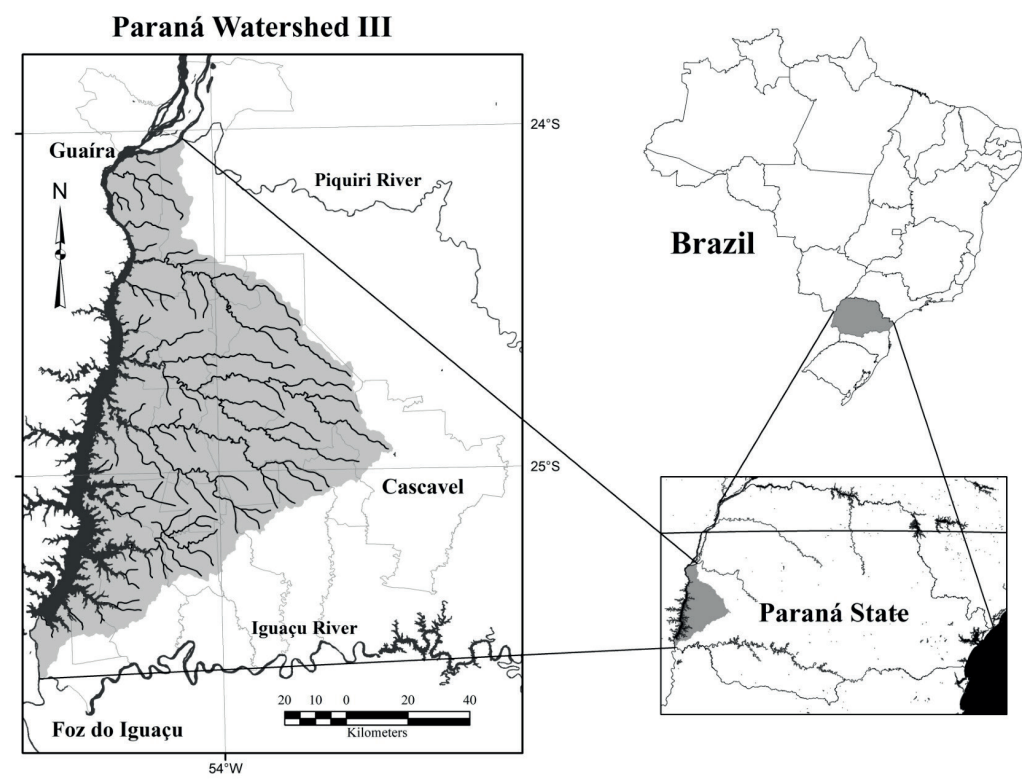

Figure 1 - Study area location. 
used on sloped land to protect crops; and (c) crop rotation - the alternation of grasses, legumes and other crops, possibly intercalated with fallow periods. Based on this information, 8 combinations were established: (i) contour farming alone, (ii) agricultural terraces alone, (iii) crop rotation alone, (iv) contour farming and terraces, (v) contour farming and crop rotation, (vi) terraces and crop rotation, (vii) all three conservation practices and (viii) none of the conservation practices considered.

The PB3 municipalities were clustered using Ward's method (hierarchical cluster analysis) and classified according to soil and water conservation practices. This pattern was related to the soil classes in PB3 (Bhering and Santos 2008) to highlight the limitations and quality problems of NT.

Data were processed using the Statistical Package for Social Sciences version 22.0. ArcGIS 10 software was used to prepare the maps.

\section{RESULTS}

Among the farms with annual crops in PB3, 66\% use NT, and the other $34 \%$ use minimum tillage or conventional tillage. In terms of area, $89 \%$ of the region is managed with NT. Figure 2 shows that 14 of the 29 PB3 municipalities use NT in more than $91 \%$ of the area dedicated to temporary crops; these municipalities are mainly located in the central region of the watershed. The area dedicated to annual crops managed by NT ranges from 71 to $90 \%$ of the total in 10 municipalities, from 51 to $70 \%$ in 3 and from 38 to $50 \%$ in 2 .

Table I shows the data regarding the level of adoption of NT combined with contour farming, agricultural terraces and crop rotation. In 22 municipalities ( $73 \%$ of the total), farms use NT combined with at least 2 of the other conservation practices; however, NT combined with all other conservation practices is predominant in only 3 municipalities. Notably, the Nova Santa Rosa municipality is the most conservation savvy PB3

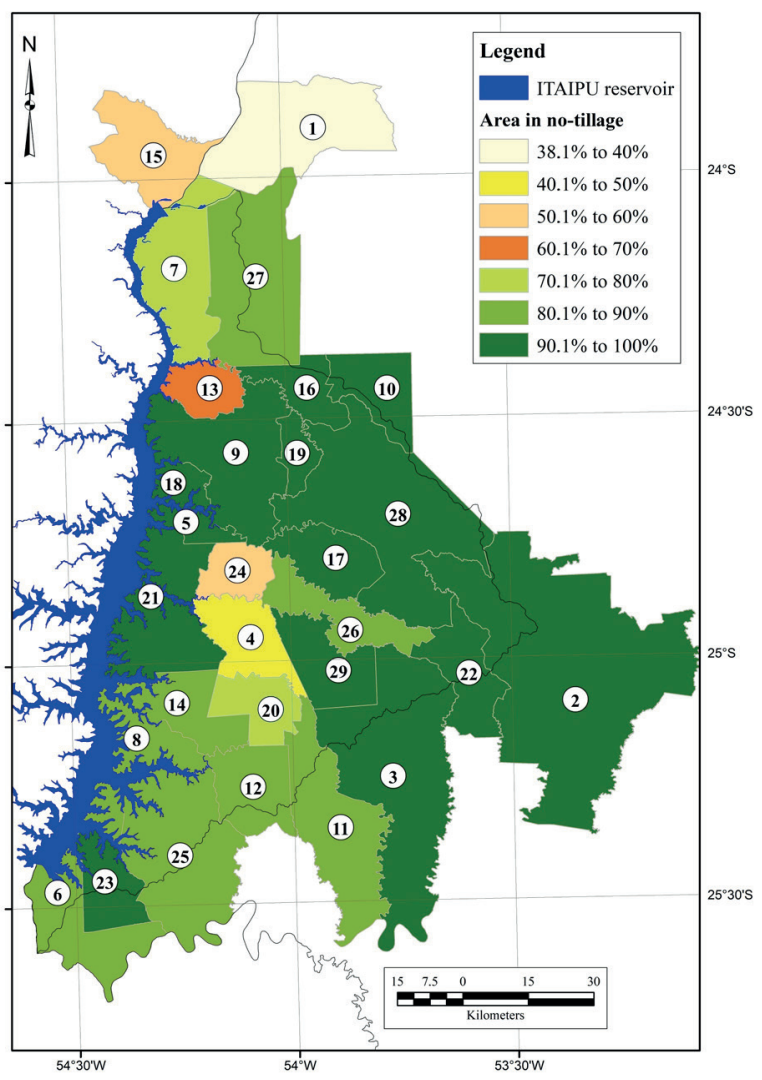

Figure 2 - Percentage of the area used with no-tillage (PD) in areas of annual crops in the Paraná Watershed III (PB3). Notes: 1. Altônia. 2. Cascavel. 3. Céu Azul. 4. Diamante D’Oeste. 5. Entre Rios do Oeste. 6. Foz do Iguaçu. 7. Guaíra. 8. Itaipulândia. 9. Marechal Cândido Rondon. 10. Maripá. 11. Matelândia. 12. Medianeira. 13. Mercedes. 14. Missal. 15. Mundo Novo. 16. Nova Santa Rosa. 17. Ouro Verde do Oeste. 18. Pato Bragado. 19. Quatro Pontes. 20. Ramilândia. 21. Santa Helena. 22. Santa Tereza do Oeste. 23. Santa Terezinha de Itaipu. 24. São José das Palmeiras. 25. São Miguel do Iguaçu. 26. São Pedro do Iguaçu. 27. Terra Roxa. 28. Toledo. 29. Vera Cruz do Oeste.

municipality, with $78 \%$ of farms adopting all practices. In contrast, NT combined with contour farming and crop rotation is predominant in the Itaipulândia municipality ( $79 \%$ of the total), but there is practically no adoption of terracing. In the other 7 municipalities in PB3, NT is used alone or combined with one conservation practice, with most farms using NT together with contour farming. In addition, agricultural terraces are generally the least used conservation practice in PB3. 
TABLE I

Conservation practices adopted by farms that use NT for annual crops in Paraná Watershed III (expressed as a percentage).

\begin{tabular}{|c|c|c|c|c|c|c|c|c|}
\hline Municipalities & None & $\mathbf{C P}$ & AT & CR & $\mathbf{C P}+\mathbf{A T}$ & $\mathrm{CP}+\mathrm{CR}$ & $\mathbf{A T}+\mathbf{C R}$ & All \\
\hline Altônia & 6.90 & 55.17 & 0.00 & 0.00 & 24.14 & 0.00 & 6.90 & 6.90 \\
\hline Cascavel & 0.31 & 47.85 & 12.61 & 2.90 & 13.80 & 15.99 & 0.22 & 6.33 \\
\hline Céu azul & 1.31 & 12.55 & 3.00 & 0.75 & 3.56 & 38.01 & 5.62 & 35.21 \\
\hline Diamante D’Oeste & 0.81 & 82.93 & 7.32 & 4.07 & 0.00 & 2.44 & 0.81 & 1.63 \\
\hline Entre Rios do Oeste & 0.00 & 12.06 & 2.51 & 12.56 & 21.61 & 5.03 & 1.01 & 45.23 \\
\hline Foz do Iguaçu & 2.91 & 50.49 & 0.00 & 37.38 & 0.49 & 1.94 & 0.49 & 6.31 \\
\hline Guaíra & 0.22 & 29.89 & 1.54 & 5.27 & 2.86 & 38.24 & 6.15 & 15.82 \\
\hline Itaipulândia & 0.57 & 14.29 & 0.00 & 5.71 & 0.00 & 79.43 & 0.00 & 0.00 \\
\hline Marechal Cândido Rondon & 0.27 & 10.72 & 3.35 & 1.50 & 1.37 & 42.90 & 0.68 & 39.21 \\
\hline Maripá & 0.36 & 6.00 & 16.36 & 1.09 & 30.73 & 6.00 & 5.09 & 34.36 \\
\hline Matelândia & 1.59 & 29.09 & 1.36 & 1.36 & 15.45 & 3.18 & 2.05 & 45.91 \\
\hline Medianeira & 1.30 & 16.23 & 8.60 & 9.90 & 4.22 & 26.30 & 1.79 & 31.66 \\
\hline Mercedes & 0.63 & 4.43 & 0.00 & 2.22 & 3.16 & 30.70 & 2.85 & 56.01 \\
\hline Missal & 0.28 & 22.68 & 0.28 & 6.62 & 2.82 & 25.21 & 2.68 & 39.44 \\
\hline Nova Santa Rosa & 0.23 & 5.67 & 0.45 & 0.68 & 2.95 & 6.80 & 5.44 & 77.78 \\
\hline Ouro Verde do Oeste & 0.00 & 17.19 & 0.29 & 2.01 & 1.72 & 44.70 & 0.57 & 33.52 \\
\hline Pato Bragado & 0.00 & 37.15 & 0.00 & 19.76 & 0.40 & 26.48 & 1.19 & 15.02 \\
\hline Quatro Pontes & 0.29 & 37.07 & 0.29 & 0.57 & 7.76 & 4.89 & 0.29 & 48.85 \\
\hline Ramilândia & 0.00 & 51.43 & 0.71 & 0.71 & 17.86 & 4.29 & 0.00 & 25.00 \\
\hline Santa Helena & 0.30 & 25.59 & 0.39 & 12.99 & 1.67 & 21.95 & 6.50 & 30.61 \\
\hline Santa Tereza do Oeste & 0.61 & 34.36 & 3.07 & 10.12 & 3.68 & 17.18 & 1.53 & 29.45 \\
\hline Santa Terezinha de Itaipu & 0.00 & 7.79 & 0.00 & 13.42 & 3.90 & 34.63 & 0.43 & 39.83 \\
\hline São José das Palmeiras & 0.00 & 30.77 & 5.49 & 9.89 & 6.59 & 35.16 & 4.40 & 7.69 \\
\hline São Miguel do Iguaçu & 0.70 & 21.35 & 2.72 & 9.97 & 23.56 & 17.12 & 2.01 & 22.56 \\
\hline São Pedro do Iguaçu & 0.00 & 56.81 & 15.18 & 0.39 & 12.45 & 11.28 & 3.11 & 0.78 \\
\hline Terra Roxa & 0.13 & 15.13 & 6.13 & 3.13 & 5.25 & 12.50 & 1.88 & 55.88 \\
\hline Toledo & 0.64 & 16.07 & 0.46 & 2.69 & 2.05 & 45.37 & 0.78 & 31.95 \\
\hline Vera Cruz do Oeste & 0.20 & 21.93 & 4.92 & 4.51 & 15.37 & 14.34 & 3.89 & 34.84 \\
\hline Mundo Novo & 3.23 & 25.81 & 3.23 & 3.23 & 16.13 & 12.90 & 0.00 & 35.48 \\
\hline
\end{tabular}

Notes: None: does not use contour farming, agricultural terraces or crop rotation. CP: uses contour farming only. AT: uses agricultural terraces only. $\mathrm{CR}$ : uses crop rotation only. $\mathrm{CP}+\mathrm{AT}$ : uses contour farming and terraces. $\mathrm{CP}+\mathrm{CR}$ : uses contour farming and crop rotation. $\mathrm{AT}+\mathrm{CR}$ : uses terraces and crop rotation. All: uses contour farming, agricultural terraces and crop rotation.

Figure 3 shows the cluster analysis of the PB3 municipalities. Five homogeneous clusters were formed based on the soil and water conservation practices. The first was composed by 3 municipalities, the second by 7 , the third by 1 , the fourth by 12 and the fifth by 6 .

Cluster 1 is composed by the municipalities with the best soil conservation practices, that is, where NT is used in combination with the other three conservation practices (contour farming, agricultural terraces and crop rotation). Cluster 2 includes the municipalities in which the farms use NT combined with 1 or 2 conservation practices, namely, contour farming and terraces. Cluster 3 includes the Itaipulândia municipality alone, where NT is used with 2 other practices: contour 
farming and crop rotation. Cluster 4 comprises the municipalities that use NT plus 1 or 2 practices, namely, contour farming or contour farming and crop rotation. Cluster 5 is represented by the less conservationist municipalities, where farms use NT combined with one conservation practice, predominantly contour farming.

Figure 4 shows the PB3 soil map, with the exception of the Mundo Novo municipality. Nitossolos vermelhos (Rhodudults) and Latossolos Vermelhos (Hapludox) soils are present throughout the watershed, but in Altônia, in the northern region of the watershed, there is a high incidence of Argissolos vermelhos soils (Paleudult). In the municipalities of Diamante D'Oeste, São José das Palmeiras, Ramilândia, Céu Azul and in the southern area of Cascavel, which are in the central region of the watershed, there is a considerable area with Neossolos Regolíticos soil (Udorthents).

\section{DISCUSSION}

Of the PB3 farms, $66 \%$ use NT and represent $89 \%$ of the watershed area, indicating the predominance of this system over conventional and minimum tillage. These findings show that although most of the area with annual crops is managed using NT, there are a significant number of farms, particularly small farms, that still do not use this practice.

In addition, it is important to analyze the quality of NT as a soil management technique because of its predominance in PB3. That is, the frequency of NT use in combination with other conservation practices must be evaluated to assess the soil and water conservation practices in this area. In Brazil, the NT quality refer to adoption of a set of soil management practices focused in minimum soil disturbance through tillage, which include NT, crop rotation, maintenance of permanent or semi-permanent soil cover (either through use of previous crop residue or by specifically growing a cover crop for this purpose), associated with

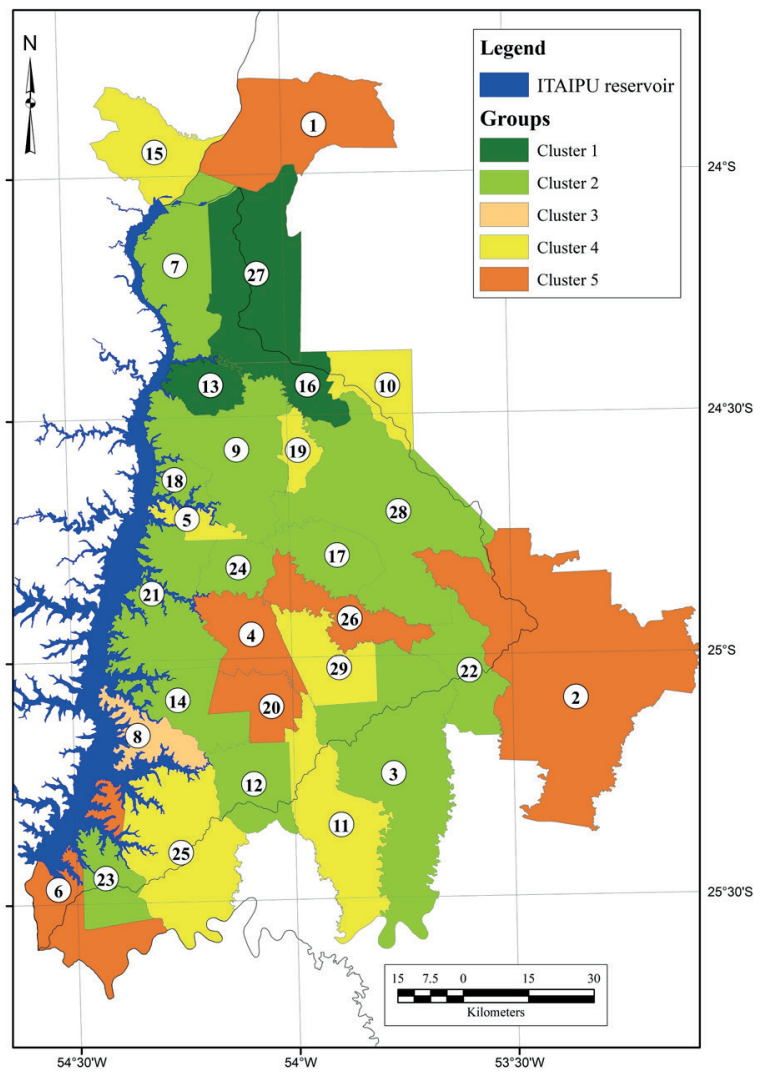

Figure 3 - Clusters of the municipalities of Paraná Watershed III (PB3) as a function of soil and water conservation practices. Notes: 1. Altônia. 2. Cascavel. 3. Céu Azul. 4. Diamante D’Oeste. 5. Entre Rios do Oeste. 6. Foz do Iguaçu. 7. Guaíra. 8. Itaipulândia. 9. Marechal Cândido Rondon. 10. Maripá. 11. Matelândia. 12. Medianeira. 13. Mercedes. 14. Missal. 15. Mundo Novo. 16. Nova Santa Rosa. 17. Ouro Verde do Oeste. 18. Pato Bragado. 19. Quatro Pontes. 20. Ramilândia. 21. Santa Helena. 22. Santa Tereza do Oeste. 23. Santa Terezinha de Itaipu. 24. São José das Palmeiras. 25. São Miguel do Iguaçu. 26. São Pedro do Iguaçu. 27. Terra Roxa. 28. Toledo. 29. Vera Cruz do Oeste.

agricultural terraces (a mechanic technique of soil conservation that control the waste failure and erosion process) and contour farming (an edaphic technique that increase of soil roughness and, consequently, reduces surface runoff). The partial adoption of soil and water conservation practices (NT, crop rotation and cover crop, agricultural terraces and contour farming) is a global problem, and the results obtained for PB3 are an example of this problematic in Brazil. The same problems have 


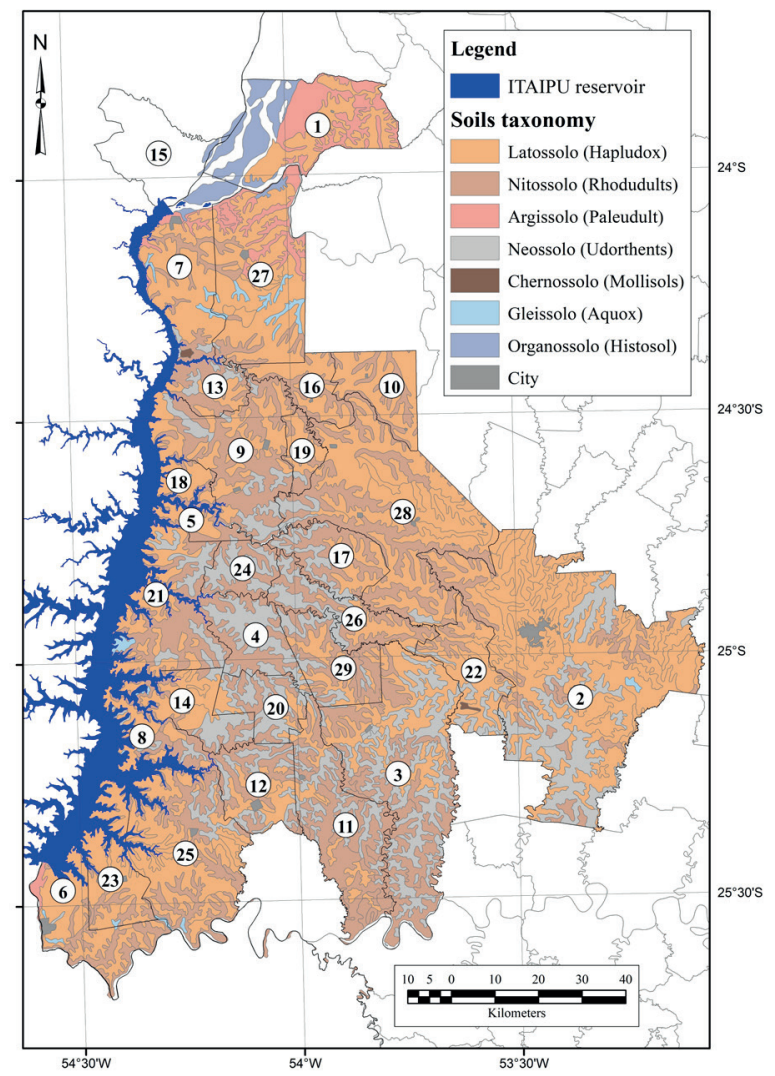

Figure 4 - Map of soils of the Paraná Watershed III (PB3). Source: prepared from Bhering and Santos (2008). Notes: 1. Altônia. 2. Cascavel. 3. Céu Azul. 4. Diamante D’Oeste. 5. Entre Rios do Oeste. 6. Foz do Iguaçu. 7. Guaíra. 8. Itaipulândia. 9. Marechal Cândido Rondon. 10. Maripá. 11. Matelândia. 12. Medianeira. 13. Mercedes. 14. Missal. 15. Mundo Novo. 16. Nova Santa Rosa. 17. Ouro Verde do Oeste. 18. Pato Bragado. 19. Quatro Pontes. 20. Ramilândia. 21. Santa Helena. 22. Santa Tereza do Oeste. 23. Santa Terezinha de Itaipu. 24. São José das Palmeiras. 25. São Miguel do Iguaçu. 26. São Pedro do Iguaçu. 27. Terra Roxa. 28. Toledo. 29. Vera Cruz do Oeste.

been observed in other parts of the world, such as in Africa, the Caribbean (Knowler and Bradshaw 2007, Giller et al. 2009), Europe (Lahmar 2010), the United States (Huggins and Reganold 2008), Canada (Kassam et al. 2009) and Australia (Greiner et al. 2009).

Even with the dissemination of NT among farmers, most soils in PB3 are still inadequately managed (Figure 3). Terracing is the least used conservation practice in the agricultural areas of these municipalities, although contour farming is used, with or without crop rotation (Table I). Didoné et al. (2014) and Le Gall et al. (2017) observed that the lack of additional measures to control surface runoff, such as crop rotation and terraces, can result in erosion problems in NT areas.

It is difficult to precisely determine why farmers do not use terraces in PB3. It is possible that the choice to plant soybeans and maize (second harvest) requires farmers to eliminate terraces, mainly due to short-term economic factors and the need to intensify agricultural mechanization to establish, maintain and harvest these crops. This theory also explains the low level of adoption of crop rotation in PB3. Another important factor may be related to the lack of knowledge of conservation systems among farmers or even difficulties in disseminating these technologies in PB3.

Each region is unique regarding the adoption of soil conservation technologies, but the overall lack of knowledge and intensification of mechanization are common factors that limit the adoption of soil conservation techniques by farmers in several countries, as highlighted by Knowler and Bradshaw (2007), Lahmar (2010) and Corbeels et al. (2014). According to these authors, the lack of knowledge also leads to difficulties in developing planting systems that are sustainable and profitable. Therefore, although farmers are aware of the environmental and economic benefits of conservation practices, they believe that the benefits do not outweigh the costs.

Among the conservation practices considered in this study, specifically terracing, Tarolli et al. (2014) observed a tendency to abandon this conservation technique among rural farmers in Africa, Nepal, China and Spain, mainly due to increasing agricultural mechanization. From the perspective of farmers, terracing increases the number of maneuvers required by machines in the field, which raises production costs (Garcia and Righes 2008). 
Crop rotation is the second least used soil conservation technique in PB3, and the characteristics of soybean and maize commodities lead to difficulty in adopting this soil conservation technique, which results in low straw production and, consequently, low soil cover. Huggins and Reganold (2008) observed the negative influence of agricultural commodities on the adoption of crop rotation in the USA, where the high price of ethanol has led to the adoption of maize monocultures among farmers. According to these authors, crop rotation, which is one of the pillars of $\mathrm{CA}$, must be economically attractive to the farmer because monoculture and crop succession practices do not yield an environmentally sustainable management system.

Of the three conservation techniques analyzed, contour farming is the most commonly used in PB3, but Silva and De Maria (2011) emphasized that this technique alone is not sufficient to control runoff.

From a soil conservation perspective, it is important to emphasize that the municipalities characterized by farms with low-quality NT are in areas with a predominance of highly erodible soils, such as Nitossolos Vermelhos (Rhodudults), Neossolos Regolíticos (Udorthents) and Argissolos vermelhos (Paleudult), Nitossolos (Rhodudults), Neossolos (Udorthents) soils are mainly present in the central-southeast region, and Argissolos (Paleudult) are found in the northern portion of PB3 and are highly susceptible to water erosion when intensively cultivated (Merten et al. 2015). It should be noted that the use of NT combined with contour farming may not be sufficient to control runoff in soils with high erodibility, thereby enhancing erosion processes.

The results of this study reflect the need to increase the dissemination of knowledge about soil and water conservation techniques among farmers in PB3 and improve the use of terraces and crop rotation in combination with NT. In addition, the results indicate that these knowledge dissemination measures can be mainly targeted at municipalities in areas with highly erodible soils.

In summary, farmers do not implement soil conservation measures as they should. Specifically, they do not use NT in combination with crop rotation, agricultural terraces and contour farming. The modus operandi and the decisions made by farmers are mainly based on the commodities market and not on the scientifically-based recommendations of rural extension agents, as would be expected.

\section{CONCLUSIONS}

NT is used in $89 \%$ of the PB3 area cultivated with annual crops. Contour farming is the conservation technique most widely used by farmers in PB3. Agricultural terracing is the conservation practice least used by farmers in PB3.

The Medianeira, Nova Santa Rosa and Terra Roxa municipalities exhibited good soil conservation practices, as NT is used in combination with terraces, contour farming and crop rotation. The Altônia, Diamante do Oeste, Ramilândia and São Pedro do Iguaçu municipalities exhibited poor soil conservation practices and predominantly use NT combined with contour farming without the use of terraces or crop rotation in areas with highly erodible soils.

\section{ACKNOWLEDGMENTS}

This work was supported by the Conselho Nacional de Desenvolvimento Científico e Tecnológico (CNPq) [grant number 429050/2016-0], and the Itaipu Binacional.

\section{AUTHOR CONTRIBUTIONS}

TST and GMCB conceived the study conceptualization. TST conducted the data curation, methodology, formal analysis, and writing, review and editing. MAPL assisted in the data curation, 
formal analysis, and writing. JFO collaborated in the writing. GVC has contributed with methodology. GMCB performed the project administration. All authors reviewed the manuscript.

\section{REFERENCES}

BARBOSA FT, BERTOL I, WERNER RS, RAMOS JC AND RAMOS RR. 2012. Comprimento crítico de declive relacionado à erosão hídrica, em três tipos e doses de resíduos em duas direções de semeadura. Rev Bras Cienc Solo 36: 1279-1290.

BHERING SB AND SANTOS HG (Eds). 2008. Mapa de solos do Estado do Paraná: Legenda Atualizada. Rio de Janeiro: Embrapa Floresta, Embrapa Solos, Instituto Agronômico do Paraná, 74 p.

CORBEELS M ET AL. 2014. Understanding the impact and adoption of conservation agriculture in Africa: a multi-scale analysis. Agr Ecosyst Environ 187: 155-170.

DECHEN SCF, TELLES TS, GUIMARÃES MF AND DE MARIA IC. 2015. Losses and costs associated with water erosion according to soil cover rate. Bragantia 74: 224233.

DENARDIN JE, KOCHHANN RA, FAGANELLO A, SATTLER A AND MANHAGO DD. 2008. "Vertical mulching" como prática conservacionista para manejo de enxurrada em sistema plantio direto. Rev Bras Cienc Solo 32: 2847-2852.

DIDONÉ EJ, MINELLA JPG AND MERTEN GH. 2015. Quantifying soil erosion and sediment yield in a catchment in southern Brazil and implications for land conservation. J Soil Sediment 15: 2334-2346.

DIDONÉ EJ, MINELLA JPG, REICHERT JM, MERTEN GH, DALBIANCO L, BARRROS CAP AND RAMON R. 2014. Impact of no-tillage agricultural systems on sediment yield in two large catchments in Southern Brazil. J Soil Sediment 14: 1287-1297.

FUENTES-LLANILLO R, DEL GROSSI ME, SANTOS FO, MUNHOS PD AND GUIMARÃES MF. 2006. Regionalização da agricultura do estado do Paraná. Cienc Rural 36: 120-127.

FUENTES-LLANILLO R, TELLES TS, SOARES JÚNIOR D AND PELINNI T. 2013. Tillage systems on annual crops in Brazil: Figures from the 2006 Agricultural Census. Semina: Cienc Agrar 34: 3691-3698.

GARCIA SM AND RIGHES AA. 2008. Vertical Mulching e manejo da água em semeadura direta. Rev Bras Cienc Solo 32: 833-842.

GILLER KE, WITTER E, CORBEELS M AND TITTONELL P. 2009. Conservation agriculture and smallholder farming in Africa: The heretics' view. Field Crop Res 114: 23-34.
GREINER R, PATTERSON L AND MILLER O. 2009. Motivations, risk perceptions and adoption of conservation practices by farmers. Agr Syst 99: 86-104.

HUGGINS DR AND REGANOLD JP. 2008. No-till: the quiet revolution. Sci Am 299: 70-77.

IPARDES - INSTITUTO PARANAENSE DE DESENVOLVIMENTO ECONÔMICO E SOCIAL. 2013. Indicadores de desenvolvimento sustentável por bacias hidrográficas do Estado do Paraná. Curitiba: IPARDES, $245 \mathrm{p}$.

JIE C, JING-ZHANG C, MAN-ZHI T AND ZI-TONG G.2002. Soil degradation: a global problem endangeringsustainable development. J Geogr Sci 12: 243-252.

KASSAM A, FRIEDRICH T AND DERPSCH R. 2019. Global spread of Conservation Agriculture. Int J Environ Stud 76: 29-51.

KASSAM A, FRIEDRICH T, SHAXSON F AND PRETTY J. 2009. The spread of Conservation Agriculture: Justification, sustainability, and uptake. Int J Agric Sust 7: 292-320.

KNOWLER D AND BRADSHAW B. 2007. Farmers' adoption of conservation agriculture: A review and synthesis of recent research. Food Policy 32: 25-48.

LAHMAR R. 2010. 'Adoption of conservation agriculture in Europe: Lessons of the KASSA project'. Land Use Policy 27: 4-10.

LAL R. 2015. Restoring soil quality to mitigate soil degradation. Sustainability 7: 5875-5895.

LE GALL M, EVRARD O, DAPOIGNY A, TIECHER T, ZAFAR M, MINELLA JPG, LACEBY JP AND AYRAULT S. 2017. Tracing sediment sources in a subtropical agricultural catchment of Southern Brazil cultivated with conventional and conservation farming practices. Land Degrad Dev 28: 1426-1436.

MARIOTI J, BERTOL I, RAMOS JC, WERNER RS, PADILHA J AND BANDEIRA DH. 2013. Erosão hídrica em semeadura direta de milho e soja nas direções da pendente e em contorno ao declive, comparada ao solo sem cultivo e descoberto. Rev Bras Cienc Solo 37: 1361-1371.

MERTEN GH, ARAÚJO AG, BISCAIA RCM, BARBOSA GMC AND CONTE O. 2015. No-till surface runoff and soil losses in the Southern Brazil. Soil Till Res 152: 85-93.

MUZILLI O. 1983. Influência do sistema de plantio direto, comparado ao convencional, sobre a fertilidade da camada arável do solo. Rev Bras Cienc Solo 7: 95-102.

MUZILLI O. 2006. Manejo do solo em sistema de plantio direto. In: Casão Junior R, Siqueira R, Mehta YR and Passini JJ (Eds), Sistema plantio direto com qualidade, Londrina: IAPAR, Foz do Iguaçu: ITAIPU Binacional, p. 9-28.

RICKSON RJ, DEEKS LK, GRAVES A, HARRIS JAH, KIBBLEWHITE MG AND SAKRABANI R. 2015. Input constraints to food production: the impact of soil degradation. Food Secur 7: 351-364. 
SANTOS HG, JACOMINE PKT, ANJOS LHC, OLIVEIRA VA, LUMBRERAS JF, COELHO MR, ALMEIDA JA, CUNHA TJF AND OLIVEIRA JB (Eds). 2013. Sistema Brasileiro de Classificação de Solos, 3rd ed., Brasília, DF: Embrapa, 353 p.

SILVA AA, GALON L, FERREIRA FA, TIRONI SP, FERREIRA EA, SILVA AF, ASPIAZÚ I AND AGNES EL. 2009. Sistema de Plantio Direto na Palhada e seu impacto na agricultura brasileira. Rev Ceres 56: 496-506.

SILVA RL AND DE MARIA IC. 2011. Erosão em sistema plantio direto: influência do comprimento de rampa e da direção de semeadura. Rev Bras Eng Agric Ambient 15: 554-561.
SOIL SURVEY STAFF. 1999. Soil taxonomy. A basic system of soil classification for making and interpreting soil surveys. Handbook 436. 2nd ed., Washington, DC: Natural Resources Conservation Service, United States Department of Agriculture, $869 \mathrm{p}$.

TAROLLI P, PRETI F AND ROMANO N. 2014. Terraced landscapes: from an old best practice to a potential hazard for soil degradation due to land abandonment. Anthropocene 6: $10-25$.

TELLES TS, DECHEN SCF AND GUIMARÃES MF. 2013. Institutional landmarks in Brazilian research on soil erosion: a historical overview. Rev Bras Cienc Solo 37: 1431-1440. 